\title{
Heat Development During Medical Drilling: Influencing Factors and Examination Methods - Overview and First Results
}

\author{
OLE JUNG $^{1}$, CAROLIN LINDNER $^{2}$, SVEN PANTERMEHL $^{1}$ and MIKE BARBECK ${ }^{2}$ \\ ${ }^{1}$ Clinic and Policlinic for Dermatology and Venereology, University Medical Center Rostock, Rostock, Germany; \\ ${ }^{2}$ BerlinAnalytix GmbH, Berlin, Germany
}

\begin{abstract}
In many medical disciplines, the process of drilling into the bone plays a crucial role for the implantation or fixation of implants or reconstruction plates. During the bone drilling process, heat is generated on the drill head and within the surrounding tissue. As a result, the increased temperature can lead to thermal damage and related necrosis of the (bone) tissue. This tissue damage is dependent on different drilling parameters and can have important influence on the following tissue healing cascade and finally on implant surveillance. In this context, the present short review elucidates the current state of scientific knowledge with regard to the heat-triggering factors during the bony drilling process and how these factors can be better understood and prevented, now and in the future, through new research approaches. External and internal influencing factors during the drilling process are distinguished and methods to examine the temperature changes are compared. This mini-review further demonstrates first preliminary results of the inflammatory tissue reactions to inadequate drilling processes. Furthermore, possible solutions of new standardized ex vivo-measurement methods to better understand the factors influencing the development of heat and to reduce animal experiments are herein discussed.
\end{abstract}

Drilling is one of the most important and most frequently used methods in medicine and especially in dentistry to reconstruct, relieve or fixate hard tissue defects. For instance,

This article is freely accessible online.

Correspondence to: Dr. med. Dr. rer. biol. hum. Ole Jung, Clinic and Policlinic for Dermatology and Venereology, University Medical Center Rostock, 18057 Rostock, Germany. Tel: +49 1714738015, e-mail: ole.tiberius.jung@googlemail.com

Key Words: Drilling process, surgery, heat development, implants, bone tissue regeneration, review. dental drills can be used to create targeted and effective dental drillings (e.g., to create implant channels for tooth implants within the jawbone).

In the beginning of the 1950 s, first research results indicated that the rotation of the drill during the drilling process causes a rise of temperature in the surrounding tissue in direct dependency with the drilling speed (1). The increase in temperature during drilling is mainly caused by friction between the drill head, the bone and associated bone splinters caused by friction and by the applied pressure (2, $3)$. Due to the poor thermal conductivity of the bone tissue, the resulting heat accumulates in a confined space (2).

Until today, the study situation is highly inconsistent with regard to the various influencing factors (e.g., internal drilling parameters such as drill configuration; external influencing factors such as cooling, feed speed and rotational speed). The limit of bone damage from heat is considered to be $47^{\circ} \mathrm{C}(4-9)$. If this limit is exceeded, the suspension of the blood flow results in a reduced supply of nutrients to the affected area, which leads to bone necrosis with activation of the osteoclasts that break down the bone as well as a build-up of inferior connective tissue in the area $(4,5,7,8$, 10-13). Clinical consequences include implant loss and fractures, leading to further surgeries and thus to an overall monetary burden on the health sector (14-17). This article is, therefore, intended to provide an introduction into the fundamentals of the various factors affecting the drilling process in order to generate basic ideas for further research efforts in this area.

\section{Influences of Different Factors}

Internal factors. The internal factors influencing heat generation during the drilling process can be distinguished as follows:

Drill properties: According to Figure 1, the drill diameter, the drill shape and the drill material have the most influence on the temperature development. These are: A) 
Drill diameter: The study situation is not clear. Some studies describe higher temperatures with increasing diameter, while other studies have shown higher temperatures when small diameters are used $(3,11,18-26)$. B) Splinters grooves/Splinter surfaces: The size, number and angle of the chip flutes can have an influence on the temperature development. For example, a drill with three flutes and a smaller angle transports the temperature more effectively to the outside due to its higher cutting efficiency $(2,11,14,27$, 28). In contrast, a larger angle would cause a higher temperature rise. C) Clear angle and open space: The previous study situation is not clear on this point. It can be assumed that higher clearance angles lead to lower temperatures. However, higher clearance angles in turn lead to larger open spaces, which can cause an increase in temperature $(14,29$ 31). Therefore, more research on this point is necessary. D) Point angles: Narrow point angles prevent the drill from slipping due to an improved attachment at the beginning of the drilling process, resulting in lower temperatures $(14,19$, $29,30,32-35)$. However, narrow point angles can lead to reduced contact of the cutting surface with the bone, which can increase the drilling time and temperature. Here again, the study situation is ambiguous $(14,19,29,30,32-35)$.

Drill alloy/coating: The alloy of the drill heads can have a major influence on the temperature increase within the (bone) tissue during the drilling process. For example, titanium-nickel-alloys cause less heat development compared to titanium-boron-nitride (36-39). Due to the large number of different alloys and coatings on the market, further studies are necessary on this point (36-39).

Wear: Multiple usage or wear of the drill leads to a stronger surface roughness and thus to higher friction and temperature increase (40-43). Clear recommendations and investigations are lacking (40-43).

External factors. External factors are considered:

Drilling speed/feed rate: The study results on this point are ambiguous. Some studies showed an inverse relationship between drilling speed/feed rate and temperature development, while other studies found higher temperatures at higher speed rates $(1,15-20,25,36,40,46-50)$.

Drilling energy: Drilling energy is defined as the energy required to produce a borehole. Generally, the smaller the drilling energy, the smaller the heat development. The drilling energy in turn depends on factors such as the angle applied, the applied drill or the formation of bone splinters $(14,29,34,35)$.

Cooling: Sufficient cooling and flushing can prevent a temperature rise above the limit value of $47^{\circ} \mathrm{C}(2,9,35)$. There are different opinions or inconsistent results in the literature on the different cooling systems (internal vs. external cooling), the quantity to be used and the temperature of the liquid $(45,51-55)$.

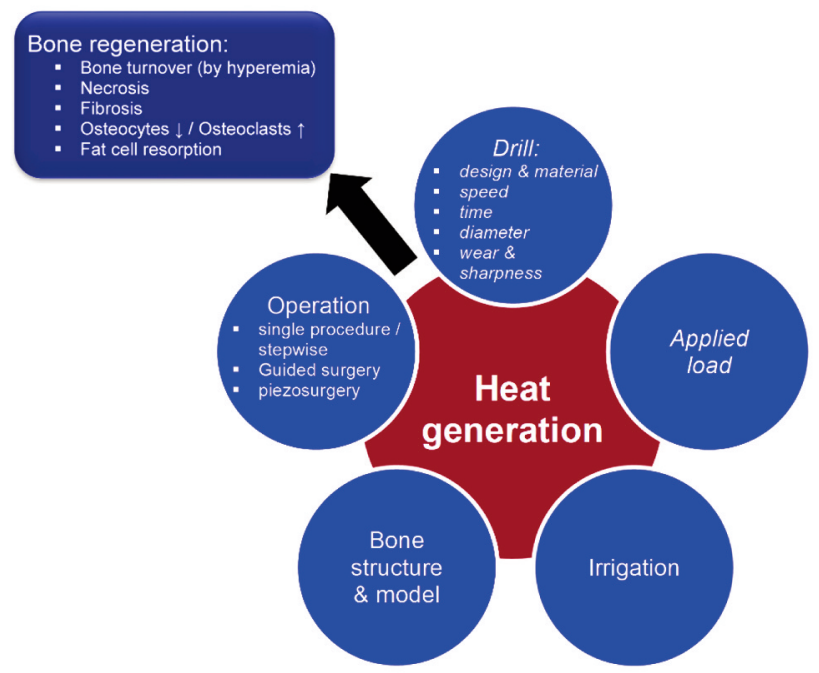

Figure 1. Diagram of heat generation during drilling with its influencing factors and its effects on bone regeneration $(44,45)$.

Drilling depth: The drilling depth depends mainly on the thickness of the cortex. The greater the drilling depth, the higher the temperature during the drilling process $(3,6,35)$.

Methodology used: Some studies were able to show that a multi-stage procedure can reduce the temperature in the bone, while others showed no reduction $(3,15,56-58)$. The results on the use of surgical drilling templates are inconsistent (59-61).

Patient individual factors. In addition, patient-specific factors can also have an influence on the temperature increase during the drilling process in the bone. The most important influencing factor is the bone mineral density. At a high bone mineral density, which depends on the localisation of the bone and patient-specific factors such as age and sex, significantly more heat is generated during drilling $(14,36)$.

\section{Research Methods and Results}

With regard to the recording and evaluating temperatures during drilling, various methods have been used. In addition to simulation using the finite element method (FEM), thermocouples, non-contact pyrometers and infrared thermography are used for metrological recording $(41,44,62-$ 68). The most efficient and easy-to-use methods are pyrometry and thermography, which are compared in Table I $(41,44)$.

\section{Preliminary In Vivo Results}

To analyse the influence of the drilling speed onto tissue reaction and bone tissue regeneration process, a preclinical 
Table I. Comparability of the two easiest to use non-contact temperature measurement methods in dental drilling $(41,44,69,70)$.

\begin{tabular}{lcc}
\hline Method name & Recording method & Type of temperature measurement \\
\hline Pyrometry & $\begin{array}{c}\text { Thermal radiation is displayed at } \\
\text { a "radiation thermometer" } \\
\text { Thermal radiation is displayed } \\
\text { as a "temperature picture" }\end{array}$ & $\begin{array}{c}\text { Accurate and efficient measurement of the thermal } \\
\text { trans-mission for point like information } \\
\text { Overview of the thermal diffusion between } \\
\text { thermography }\end{array}$ \\
\hline
\end{tabular}
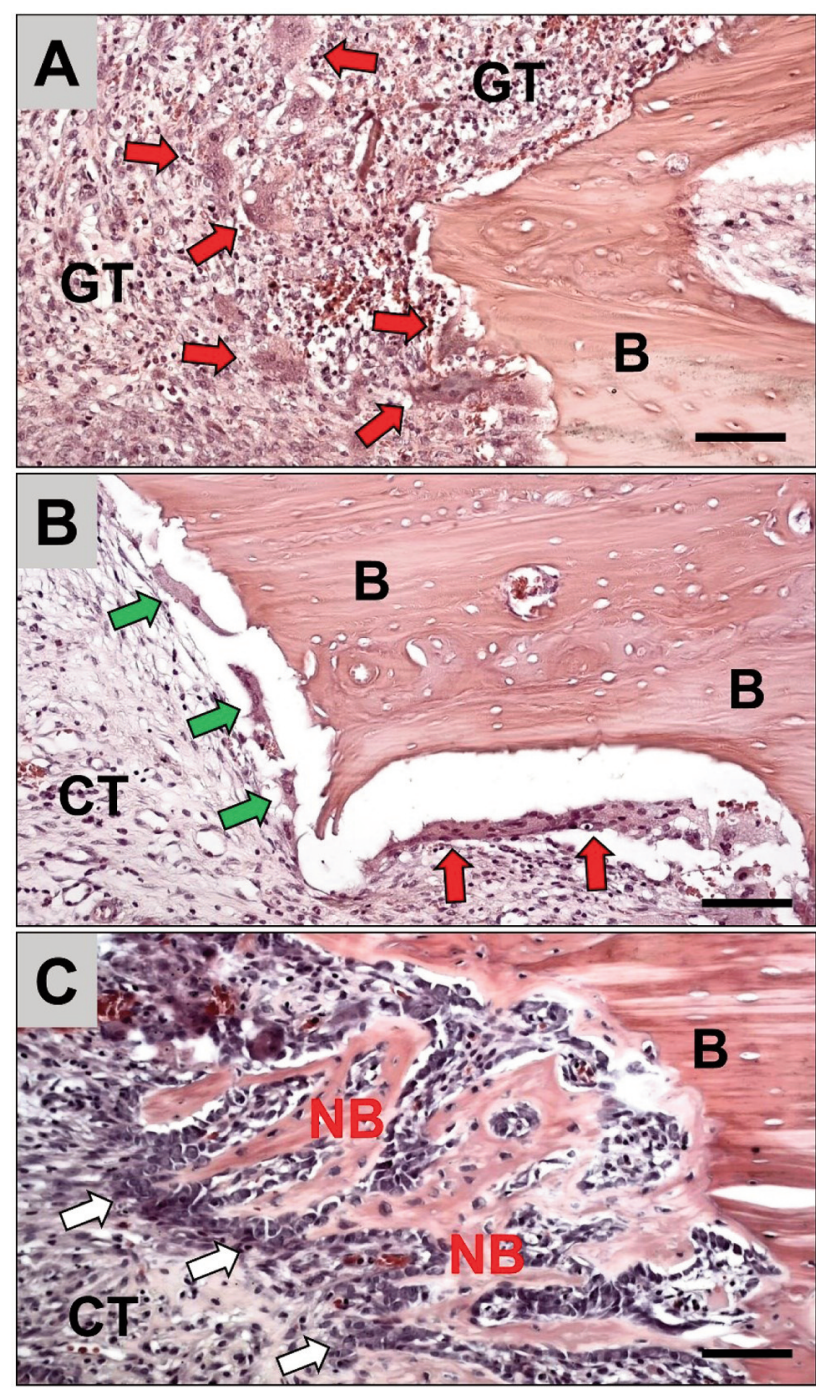

Figure 2. Exemplary histological images showing the cellular consequences of $(A)$ high heat, $(B)$ medium heat and $(C)$ low heat during drilling at day 30 after surgery. (A) The image shows that high drillinginduced heat causes a high extent of inflammation associated with development of granulation tissue (GT) and high numbers of multinucleated giant cells (MNGCs, red arrows) resorbing the neighboured bone matrix (B). (B) Medium drilling-induced heat caused a lower extent of inflammation but also MNGC-induction. CT: Connective tissue, B: bone matrix. (C) Low drilling-induced temperature allows for growth of new bone tissue $(N B)$ with the involvement of active osteoblasts (white arrows) (HE-staining, 400 $\times$ magnification, scale bars $=100 \mu \mathrm{m})$.

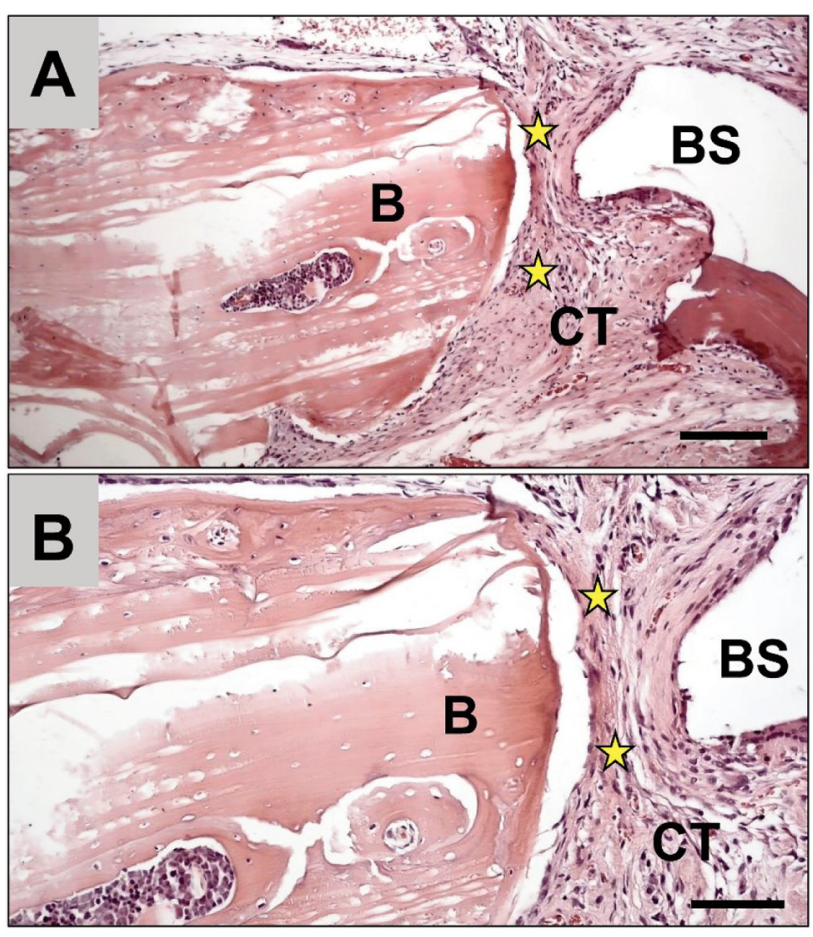

Figure 3. Exemplary histological images showing the consequences of high heat during drilling at day 60 after surgery. The images show that high drilling-induced heat causes a fibrosis-like (yellow stars) separation of the neighbouring bone tissue $(B)$ without any formation of new bone matrix resulting in a lack of bony integration of bone substitute granules (BS) (HE-staining, A: 100x magnification, B: 200x magnification, scale bars $=100 \mu \mathrm{m})$.

in vivo study was conducted based on previously published methods using the calvaria implantation model (71-75). The preliminary data reveal that the inflammatory tissue reactions increase with rises in temperature (Figure 2, Figure 3, Figure 4 and Figure 5). Thereby heat-induced damages not only lead to an inflammation-based degradation of the neighbouring bone matrix (Figure 4 and Figure 5), but also to a lack of bony integration of implants such as bone substitute materials (Figure 3). From our own experience, slight changes and consideration of the influencing factors mentioned above can have a major influence on the results. 


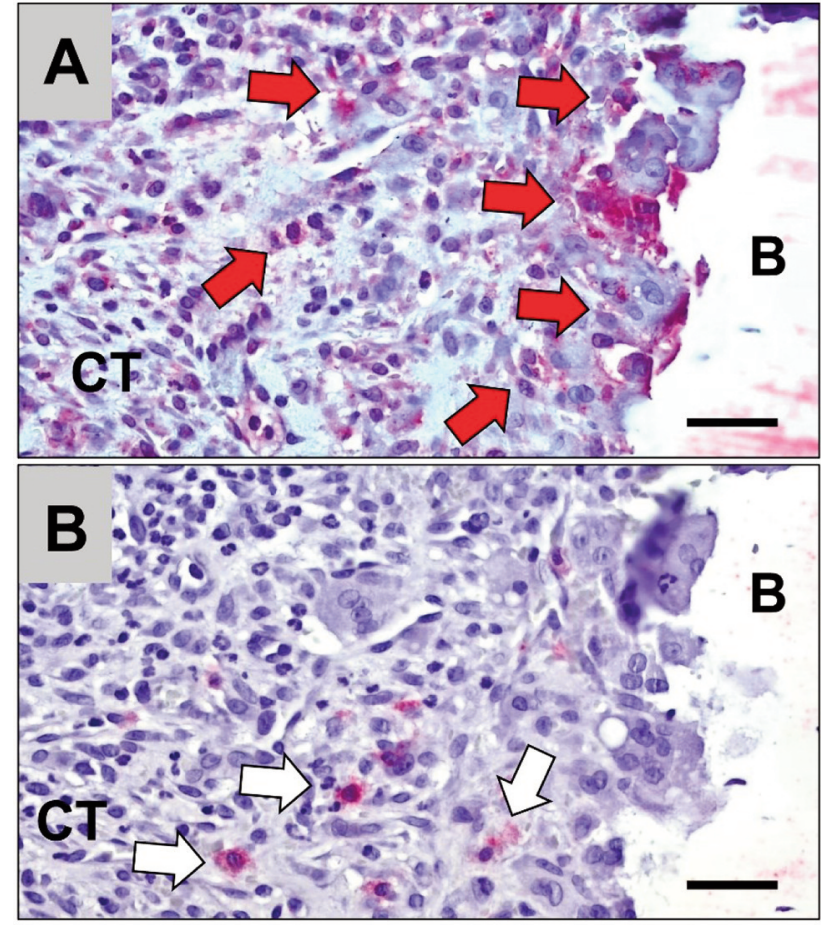

Figure 4. Exemplary histological images showing the molecular consequences of high heat during drilling at day 30 after surgery. The images show that most inflammatory cells express the pro-inflammatory CD11-molecule (read arrows, A) but not anti-inflammatory molecules such as the CD163-molecule (white arrows, B) (immuno-staining, 400X magnification, scale bar $=100 \mu \mathrm{m}$ ).

Thereby, working with sufficient cooling fluid can prevent major necrosis in hard and soft tissue. Altogether, the data of this preclinical study present new insights into tissue injuries and their molecular basis.

\section{Conclusion}

To date, there are no uniform and consistent studies on the effects of different drilling methods or drilling factors on the surrounding tissue and the survival rate of, for example, dental implants available. It is, therefore, of great importance to investigate this topic in greater detail in order to increase operational quality and, for example, implant survival. For instance, the development of a valid ex vivo test bench in order to reduce or, if possible, completely avoid animal experiments in the future are of vast interest. With regard to scientific discussions on the above-mentioned parameters, a test rig can efficiently avoid animal experiments as well as accelerate and standardize scientific investigations.

The respective advantages of all the above-mentioned temperature measurement methods have to be combined with

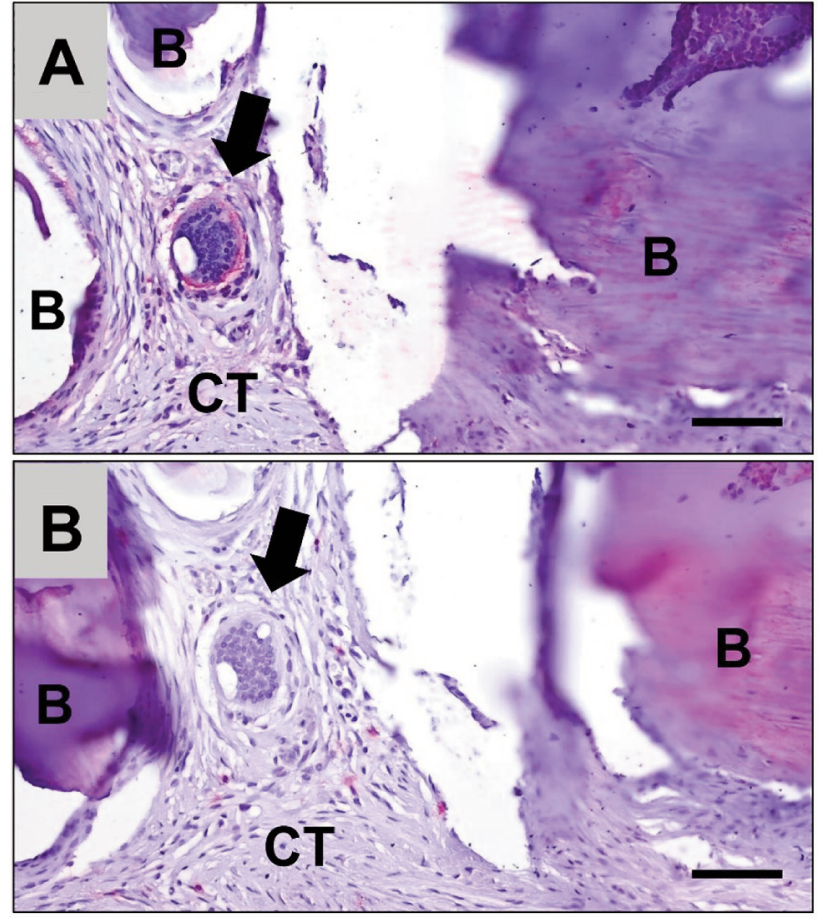

Figure 5. Exemplary histological images showing the molecular consequences of high heat during drilling at day 30 after surgery. The images show multinucleated giant cells (black arrows in A and B) expressing the pro-inflammatory CD11-molecule (A) but not the antiinflammatory CD163-molecule $(B)$, presenting their inflammatory origin (immuno-staining, 400× magnification, scale bar $=100 \mu \mathrm{m}$ ).

each other and the knowledge gained should be directly incorporated into the validation of new finite element method (FEM) models. Such new models can enable evaluation of the obtained data for detailed characterisation of the heat generation processes. A better understanding of the heat generation mechanisms contributes to targeted planning of experiments and can help reduce the number of animal experiments.

\section{Conflicts of Interest}

The Authors declare no conflicts of interest.

\section{Authors' Contributions}

Conceptualization, O.J. and M.B.; methodology, O.J. and M.B.; software, O.J. and M.B.; validation, O.J. and M.B.; formal analysis, O.J., C.L., S.P. and M.B.; investigation, O.J. and M.B.; resources, O.J. and M.B.; data curation, O.J., C.L., S.P. and M.B.; writing original draft preparation, O.J., C.L., S.P. and M.B.; writing review and editing, O.J. and M.B.; visualization, O.J. and M.B.; supervision, O.J. and M.B.; project administration, O.J. and M.B.; funding acquisition, O.J. and M.B. 


\section{References}

1 Vaughn RC and Peyton FA: The influence of rotational speed on temperature rise during cavity preparation. J Dent Res 30(5): 737744, 1951. PMID: 14888776. DOI: 10.1177/00220345 510300051801

2 Davidson SR and James DF: Measurement of thermal conductivity of bovine cortical bone. Med Eng Phys 22(10): 741-747, 2000 PMID: 11334760. DOI: 10.1016/s1350-4533(01)00003-0

3 Kalidindi V: Optimization of drill design and coolant systems during dental implant surgery, University of Kentucky Master's Theses, 2004. Available at: https://uknowledge.uky.edu/ cgi/viewcontent.cgi $?$ article $=1317 \&$ context $=$ gradschool_theses [Last accessed on September 7, 2021]

4 Eriksson A, Albrektsson T, Grane B and McQueen D: Thermal injury to bone. A vital-microscopic description of heat effects. Int J Oral Surg 11(2): 115-121, 1982. PMID: 6809671. DOI: 10.1016/s0300-9785(82)80020-3

5 Eriksson AR and Albrektsson T: Temperature threshold levels for heat-induced bone tissue injury: a vital-microscopic study in the rabbit. J Prosthet Dent 50(1): 101-107, 1983. PMID: 6576145. DOI: 10.1016/0022-3913(83)90174-9

6 Eriksson AR, Albrektsson T and Albrektsson B: Heat caused by drilling cortical bone. Temperature measured in vivo in patients and animals. Acta Orthop Scand 55(6): 629-631, 1984. PMID: 6524329. DOI: $10.3109 / 17453678408992410$

7 Eriksson RA and Adell R: Temperatures during drilling for the placement of implants using the osseointegration technique. J Oral Maxillofac Surg 44(1): 4-7, 1986. PMID: 3455722. DOI: 10.1016/0278-2391(86)90006-6

8 Eriksson RA and Albrektsson T: The effect of heat on bone regeneration: an experimental study in the rabbit using the bone growth chamber. J Oral Maxillofac Surg 42(11): 705-711, 1984. PMID: 6593442. DOI: 10.1016/0278-2391(84)90417-8

9 Eriksson RA, Albrektsson T and Magnusson B: Assessment of bone viability after heat trauma. A histological, histochemical and vital microscopic study in the rabbit. Scand J Plast Reconstr Surg 18(3): 261-268, 1984. PMID: 6549359. DOI: 10.3109/ 02844318409052849

10 Berman AT, Reid JS, Yanicko DR Jr, Sih GC and Zimmerman MR: Thermally induced bone necrosis in rabbits. Relation to implant failure in humans. Clin Orthop Relat Res (186): 284292, 1984. PMID: 6723155.

11 Augustin G, Zigman T, Davila S, Udilljak T, Staroveski T, Brezak $\mathrm{D}$ and Babic S: Cortical bone drilling and thermal osteonecrosis. Clin Biomech (Bristol, Avon) 27(4): 313-325, 2012. PMID: 22071428. DOI: $10.1016 /$ j.clinbiomech.2011.10.010

12 Tehemar SH: Factors affecting heat generation during implant site preparation: a review of biologic observations and future considerations. Int J Oral Maxillofac Implants 14(1): 127-136, 1999. PMID: 10074763.

13 Noble B: Bone microdamage and cell apoptosis. Eur Cell Mater 6: 46-55; discusssion 55, 2003. PMID: 14710370. DOI: 10. 22203/ecm.v006a05

14 Pandey RK and Panda SS: Drilling of bone: A comprehensive review. J Clin Orthop Trauma 4(1): 15-30, 2013. PMID: 26403771. DOI: 10.1016/j.jcot.2013.01.002

15 Matthews LS, Green CA and Goldstein SA: The thermal effects of skeletal fixation-pin insertion in bone. J Bone Joint Surg Am 66(7): 1077-1083, 1984. PMID: 6480636.
16 Abouzgia MB and James DF: Temperature rise during drilling through bone. Int J Oral Maxillofac Implants 12(3): 342-353, 1997. PMID: 9197099.

17 Hillery M and Shuaib I: Temperature effects in the drilling of human and bovine bone. Journal of Materials Processing Technology 9293: 302-308, 2019. DOI: 10.1016/S0924-0136(99)00155-7

18 Thompson HC: Effect of drilling into bone. J Oral Surg (Chic) 16(1): 22-30, 1958. PMID: 13492103.

19 Augustin G, Davila S, Mihoci K, Udiljak T, Vedrina DS and Antabak A: Thermal osteonecrosis and bone drilling parameters revisited. Arch Orthop Trauma Surg 128(1): 71-77, 2008. PMID: 17762937. DOI: 10.1007/s00402-007-0427-3

20 Brisman DL: The effect of speed, pressure, and time on bone temperature during the drilling of implant sites. Int $\mathrm{J}$ Oral Maxillofac Implants 11(1): 35-37, 1996. PMID: 8820120.

$21 \mathrm{Kim}$ SJ, Yoo J, Kim YS and Shin SW: Temperature change in pig rib bone during implant site preparation by low-speed drilling. J Appl Oral Sci 18(5): 522-527, 2010. PMID: 21085811. DOI: $10.1590 / \mathrm{s} 1678-77572010000500016$

22 Strbac GD, Giannis K, Unger E, Mittlböck M, Vasak C, Watzek $\mathrm{G}$ and Zechner W: Drilling- and withdrawing-related thermal changes during implant site osteotomies. Clin Implant Dent Relat Res 17(1): 32-43, 2015. PMID: 23714272. DOI: 10.1111/cid.12091

23 Strbac GD, Giannis K, Unger E, Mittlböck M, Watzek G and Zechner W: A novel standardized bone model for thermal evaluation of bone osteotomies with various irrigation methods. Clin Oral Implants Res 25(5): 622-631, 2014. PMID: 23347297. DOI: $10.1111 /$ clr.12090

24 Bogovič V, Svete A and Bajsić I: Effects of a drill diameter on the temperature rise in a bone during implant site preparation under clinical conditions. Proc Inst Mech Eng H 230(10): 907917, 2016. PMID: 27459501. DOI: 10.1177/0954411916660737

25 El-Kholey KE, Ramasamy S, Kumar R S and Elkomy A: Effect of simplifying drilling technique on heat generation during osteotomy preparation for dental implant. Implant Dent 26(6): 888-891, 2017. PMID: 29135705. DOI: 10.1097/ID.000000 0000000692

26 Tahmasbi V, Ghoreishi M and Zolfaghari M: Investigation, sensitivity analysis, and multi-objective optimization of effective parameters on temperature and force in robotic drilling cortical bone. Proc Inst Mech Eng H 231(11): 1012-1024, 2017. PMID: 28803514. DOI: $10.1177 / 0954411917726098$

27 Bertollo N, Gothelf TK and Walsh WR: 3-Fluted orthopaedic drills exhibit superior bending stiffness to their 2-fluted rivals: clinical implications for targeting ability and the incidence of drill-bit failure. Injury 39(7): 734-741, 2008. PMID: 18490018. DOI: $10.1016 /$ j.injury.2007.11.286

28 Bertollo N, Milne HR, Ellis LP, Stephens PC, Gillies RM and Walsh WR: A comparison of the thermal properties of 2- and 3fluted drills and the effects on bone cell viability and screw pullout strength in an ovine model. Clin Biomech (Bristol, Avon) 25(6): 613-617, 2010. PMID: 20359798. DOI: 10.1016/ j.clinbiomech.2010.02.007

29 Karmani S and Lam F: The design and function of surgical drills and K-wires. Current Orthopaedics 18(6): 484-490, 2020. DOI: 10.1016/J.CUOR.2004.12.011

30 Saha S, Pal S and Albright JA: Surgical drilling: design and performance of an improved drill. J Biomech Eng 104(3): 245252, 1982. PMID: 7120951. DOI: 10.1115/1.3138356 
31 Farnworth G and Burton J: Optimization of drill geometry for orthopaedic surgery. Proceedings of the Fifteenth International Machine Tool Design and Research Conference: 227-233, 2019. DOI: 10.1007/978-1-349-01986-1_27

32 Natali C, Ingle P and Dowell J: Orthopaedic bone drills-can they be improved? Temperature changes near the drilling face. J Bone Joint Surg Br 78(3): 357-362, 1996. PMID: 8636166.

33 Jacob $\mathrm{CH}$ and Berry JT: A study of the bone machining process - drilling. J Biomech: 343-349, 1976. PMID: 1270451.

34 Wiggins KL and Malkin S: Drilling of bone. J Biomech 9(9): 553-559, 1976. PMID: 965420. DOI: 10.1016/0021-9290(76) 90095-6

35 Sneath R: The determination of optimum twist drill shape for bone. Biomechanics and Related Bio-Engineering Topics: 41-45, 2018. DOI: 10.1016/B978-1-4831-6701-5.50012-7

36 Karaca F, Aksakal B and Kom M: Influence of orthopaedic drilling parameters on temperature and histopathology of bovine tibia: an in vitro study. Med Eng Phys 33(10): 1221-1227, 2011. PMID: 21703907. DOI: 10.1016/j.medengphy.2011.05.013

37 Ercoli C, Funkenbusch PD, Lee HJ, Moss ME and Graser GN: The influence of drill wear on cutting efficiency and heat production during osteotomy preparation for dental implants: a study of drill durability. Int J Oral Maxillofac Implants 19(3): 335-349, 2004. PMID: 15214217.

38 Oliveira N, Alaejos-Algarra F, Mareque-Bueno J, Ferrés-Padró $\mathrm{E}$ and Hernández-Alfaro F: Thermal changes and drill wear in bovine bone during implant site preparation. A comparative in vitro study: twisted stainless steel and ceramic drills. Clin Oral Implants Res 23(8): 963-969, 2012. PMID: 21806686. DOI: 10.1111/j.1600-0501.2011.02248.x

39 Er N, Alkan A, Ilday S and Bengu E: Improved dental implant drill durability and performance using heat and wear resistant protective coatings. J Oral Implantol 44(3): 168-175, 2018. PMID: 29498904. DOI: 10.1563/aaid-joi-D-16-00114

40 Matthews LS and Hirsch C: Temperatures measured in human cortical bone when drilling. J Bone Joint Surg Am 54(2): 297308, 1972. PMID: 4651263.

41 Scarano A, Carinci F, Quaranta A, Di Iorio D, Assenza B and Piattelli A: Effects of bur wear during implant site preparation: an in vitro study. Int J Immunopathol Pharmacol 20(1 Suppl 1): 23-26, 2007. PMID: 17897497. DOI: $10.1177 / 039463200702001$ s06

42 Chacon GE, Bower DL, Larsen PE, McGlumphy EA and Beck FM: Heat production by 3 implant drill systems after repeated drilling and sterilization. J Oral Maxillofac Surg 64(2): 265-269, 2006. PMID: 16413899. DOI: 10.1016/j.joms.2005.10.011

43 Jochum RM and Reichart PA: Influence of multiple use of Timedur-titanium cannon drills: thermal response and scanning electron microscopic findings. Clin Oral Implants Res 11(2): 139-143, 2000. PMID: 11168204.

44 Möhlhenrich SC, Modabber A, Steiner T, Mitchell DA and Hölzle F: Heat generation and drill wear during dental implant site preparation: systematic review. Br J Oral Maxillofac Surg 53(8): 679-689, 2015. PMID: 26051868. DOI: 10.1016/ j.bjoms.2015.05.004

45 Barrak I, Joób-Fancsaly A, Varga E, Boa K and Piffko J: Effect of the combination of low-speed drilling and cooled irrigation fluid on intraosseous heat generation during guided surgical implant site preparation: an in vitro study. Implant Dent 26(4): 541-546, 2017. PMID: 28542041. DOI: 10.1097/ID.0000000000000607
46 Lee J, Chavez CL and Park J: Parameters affecting mechanical and thermal responses in bone drilling: A review. J Biomech 71: 4-21, 2018. PMID: 29559242. DOI: 10.1016/j.jbiomech.2018.02.025

47 Sharawy M, Misch CE, Weller $\mathrm{N}$ and Tehemar S: Heat generation during implant drilling: the significance of motor speed. J Oral Maxillofac Surg 60(10): 1160-1169, 2002. PMID: 12378492. DOI: 10.1053 /joms.2002.34992

48 Iyer S, Weiss C and Mehta A: Effects of drill speed on heat production and the rate and quality of bone formation in dental implant osteotomies. Part II: Relationship between drill speed and healing. Int J Prosthodont 10(6): 536-540, 1997. PMID: 9495174.

49 Bachus KN, Rondina MT and Hutchinson DT: The effects of drilling force on cortical temperatures and their duration: an in vitro study. Med Eng Phys 22(10): 685-691, 2000. PMID: 11334754. DOI: 10.1016/s1350-4533(01)00016-9

50 Nam O, Yu W, Choi M and Kyung H: Monitoring of bone temperature during osseous preparation for orthodontic microscrew implants: Effect of motor speed and ressure. Key Engineering Materials 321-323: 1044-1047, 2021. DOI: 10.4028/www.scientific.net/KEM.321-323.1044

51 Sindel A, Dereci Ö, Hatipoğlu M, Altay MA, Özalp Ö and Öztürk A: The effects of irrigation volume to the heat generation during implant surgery. Med Oral Patol Oral Cir Bucal 22(4): e506-e511, 2017. PMID: 28624839. DOI: $10.4317 /$ medoral.21880

52 Lavelle C and Wedgwood D: Effect of internal irrigation on frictional heat generated from bone drilling. J Oral Surg 38(7): 499-503, 1980. PMID: 6929901.

53 Benington IC, Biagioni PA, Briggs J, Sheridan S and Lamey PJ: Thermal changes observed at implant sites during internal and external irrigation. Clin Oral Implants Res 13(3): 293-297, 2002. PMID: 12010160. DOI: 10.1034/j.1600-0501.2002.130309.x

54 Sener BC, Dergin G, Gursoy B, Kelesoglu E and Slih I: Effects of irrigation temperature on heat control in vitro at different drilling depths. Clin Oral Implants Res 20(3): 294-298, 2009. PMID: 19397641. DOI: 10.1111/j.1600-0501.2008.01643.x

55 Rashad A, Kaiser A, Prochnow N, Schmitz I, Hoffmann E and Maurer P: Heat production during different ultrasonic and conventional osteotomy preparations for dental implants. Clin Oral Implants Res 22(12): 1361-1365, 2011. PMID: 21435005. DOI: $10.1111 / \mathrm{j} .1600-0501.2010 .02126 . x$

56 Udilijak T, Ciglar D and Skoric S: Investigation into bone drilling and thermal bone necrosis. Adv Prod Eng Manag 2(3): 102-112, 2007.

57 Augustin G, Davila S, Udilljak T, Staroveski T, Brezak D and Babic S: Temperature changes during cortical bone drilling with a newly designed step drill and an internally cooled drill. Int Orthop 36(7): 1449-1456, 2012. PMID: 22290154. DOI: 10.1007/s00264-012-1491-z

58 Brånemark PI: Osseointegration and its experimental background. J Prosthet Dent 50(3): 399-410, 1983. PMID: 6352924. DOI: 10.1016/s0022-3913(83)80101-2

59 Misir AF, Sumer M, Yenisey M and Ergioglu E: Effect of surgical drill guide on heat generated from implant drilling. J Oral Maxillofac Surg 67(12): 2663-2668, 2009. PMID: 19925988. DOI: 10.1016/j.joms.2009.07.056

60 Bulloch SE, Olsen RG and Bulloch B: Comparison of heat generation between internally guided (cannulated) single drill and traditional sequential drilling with and without a drill guide for dental implants. Int J Oral Maxillofac Implants 27(6): 14561460, 2012. PMID: 23189297. 
61 Jeong SM, Yoo JH, Fang Y, Choi BH, Son JS and Oh JH: The effect of guided flapless implant procedure on heat generation from implant drilling. J Craniomaxillofac Surg 42(6): 725-729, 2014. PMID: 24332815. DOI: 10.1016/j.jcms.2013.11.002

62 D`Hodet B, Ney T, Mohlmann $\mathrm{H}$ and Luckenbach A: Temperature measurement by infrared technology during drilling process for endosseous dental implants. Z Zahnärztl Implantol 31: 123-130, 1987.

63 Horch HH and Keiditsch E: [Morphological findings on the tissue lesion and bone regeneration after laser osteotomy]. Dtsch Zahnarztl Z 35(1): 22-24, 1980. PMID: 6931726.

64 Chen Z, Klein T, Murray R, Crawford R, Chang J, Wu C and Xiao Y: Osteoimmunomodulation for the development of advanced bone biomaterials. Materials Today 19(6): 304-321, 2021. DOI: 10.1016/j.mattod.2015.11.004

65 Chen YC, Tu YK, Tsai YJ, Tsai YS, Yen CY, Yang SC and Hsiao CK: Assessment of thermal necrosis risk regions for different bone qualities as a function of drilling parameters. Comput Methods Programs Biomed 162: 253-261, 2018. PMID: 29903492. DOI: 10.1016/j.cmpb.2018.05.018

66 Tu Y-K, Chen L-W, Ciou J-S, Hsiao C-K and Chen YY: Finite element simulations of bone temperature rise during bone drilling based on a bone analog. J Med Biol Eng 33(3): 269, 2013. DOI: $10.5405 /$ jmbe. 1366

67 Chen YC, Tu YK, Zhuang JY, Tsai YJ, Yen CY and Hsiao CK: Evaluation of the parameters affecting bone temperature during drilling using a three-dimensional dynamic elastoplastic finite element model. Med Biol Eng Comput 55(11): 1949-1957, 2017. PMID: 28353132. DOI: 10.1007/s11517-017-1644-8

68 Chen YC, Hsiao CK, Ciou JS, Tsai YJ and Tu YK: Effects of implant drilling parameters for pilot and twist drills on temperature rise in bone analog and alveolar bones. Med Eng Phys 38(11): 1314-1321, 2016. PMID: 27645310. DOI: 10.1016/j.medengphy.2016.08.009

69 Glückert UL: Pyrometry and thermography. Optical Measurements: 315-347, 2019. DOI: 10.1007/978-3-662-02967-1_15

70 Shiwa M and Kishi T: Ndt-based assessment of damage: An overview. In: Encyclopedia of materials: Science and technology. Buschow KHJ, Cahn RW, Flemings MC, Ilschner B, Kramer EJ, Mahajan S and Veyssière P (eds.). Elsevier, Oxford, pp. 1-8, 2005.
71 Barbeck M, Booms P, Unger R, Hoffmann V, Sader R, Kirkpatrick CJ and Ghanaati S: Multinucleated giant cells in the implant bed of bone substitutes are foreign body giant cells-New insights into the material-mediated healing process. J Biomed Mater Res A 105(4): 1105-1111, 2017. PMID: 28093892. DOI: 10.1002/jbm.a.36006

72 Barbeck M, Motta A, Migliaresi C, Sader R, Kirkpatrick CJ and Ghanaati S: Heterogeneity of biomaterial-induced multinucleated giant cells: Possible importance for the regeneration process? J Biomed Mater Res A 104(2): 413-418, 2016. PMID: 26422451. DOI: $10.1002 / \mathrm{jbm} . \mathrm{a} .35579$

73 Korzinskas T, Jung O, Smeets R, Stojanovic S, Najman S, Glenske K, Hahn M, Wenisch S, Schnettler R and Barbeck M: In vivo analysis of the biocompatibility and macrophage response of a non-resorbable PTFE membrane for guided bone regeneration. Int J Mol Sci 19(10): 2952, 2018. PMID: 30262765. DOI: $10.3390 /$ ijms 19102952

74 Sieger D, Korzinskas T, Jung O, Stojanovic S, Wenisch S, Smeets R, Gosau M, Schnettler R, Najman S and Barbeck M: The addition of high doses of hyaluronic acid to a biphasic bone substitute decreases the proinflammatory tissue response. Int $\mathrm{J}$ Mol Sci 20(8): 1969, 2019. PMID: 31013636. DOI: 10.3390/ijms20081969

75 Rolvien T, Barbeck M, Wenisch S, Amling M and Krause M: Cellular mechanisms responsible for success and failure of bone substitute materials. Int J Mol Sci 19(10): 2893, 2018. PMID: 30249051. DOI: 10.3390/ijms19102893
Received July 18, 2021

Revised August 21, 2021

Accepted September 7, 2021 